\title{
Test of SMA - 16 asphalt mixture ratio on the runway of Da Lian Airport
}

\author{
Shuaituan Tian ${ }^{1,2}$ Kunyang Zhao ${ }^{1,2, ~ *}$, Lei Guo ${ }^{1,2}$, Hanxun Wang ${ }^{3}$ \\ ${ }^{1}$ China Airport Construction Group Co., Ltd, Beijing, 100101, China \\ ${ }^{2}$ Beijing Super-Creative Technology Co., Ltd, Beijing, 100621, China \\ ${ }^{3}$ School of Engineering and Technology, China University of Geosciences (Beijing), Beijing, 100083, China
}

\begin{abstract}
After years of use, there's oil loss on the asphalt pavement . the bond strength of aggregate decreases . Loose threshing is serious. In order to improve the pavement performance, Extend the service life of pavement, Improve the safety of aircraft operation .we test the SMA-16 modified asphalt mixture on the runway of Da Lian Airport from many factors, including raw materials, admixtures, gradation design, optimum ratio of oil to stone, then we find the best ways to resolve it.
\end{abstract}

\section{Introduction}

After years of use, there's oil loss on the asphalt pavement, the bond strength of aggregate decreases . Loose threshing is serious. In order to improve the pavement performance, extend the service life of pavement, improve the safety of aircraft operation, we test the SMA-16 modified asphalt mixture on the runway of Da Lian Airport from many factors, including raw materials, admixtures, gradation design, optimum ratio of oil to stone, then we find the best ways to resolve it .

\section{Raw materials}

\subsection{Asphalt}

We use high modulus asphalt and test its performance indicators, we put the results on the below table .

Table1. High modulus asphalt performance test results

\begin{tabular}{|c|c|c|c|}
\hline \multicolumn{2}{|c|}{ Test items } & $\begin{array}{l}\text { Technical } \\
\text { requirements }\end{array}$ & $\begin{array}{l}\text { Test } \\
\text { results }\end{array}$ \\
\hline \multicolumn{2}{|c|}{ Softening point $\left({ }^{\circ} \mathrm{C}\right)$} & $>80$ & 88.3 \\
\hline \multicolumn{2}{|c|}{$\begin{array}{c}\text { Penetration }\left(25^{\circ} \mathrm{C}, 100 \mathrm{~g}, 5 \mathrm{~s}\right) \\
(0.1 \mathrm{~mm})\end{array}$} & $\leqq 50$ & 36.3 \\
\hline \multicolumn{2}{|c|}{$\begin{array}{c}\text { Ductility }(5 \mathrm{~cm} / \mathrm{min}, \\
\left.10^{\circ} \mathrm{C}\right)(\mathrm{cm})\end{array}$} & $>40$ & 48.3 \\
\hline \multirow{3}{*}{$\begin{array}{c}\text { Filmy } \\
\text { heating } \\
\text { operational } \\
\text { test } 163^{\circ} \mathrm{C} / 5 \mathrm{~h}\end{array}$} & $\begin{array}{c}\text { Mass loss } \\
(\%)\end{array}$ & $<1$ & -0.04 \\
\hline & $\begin{array}{c}\text { Penetration } \\
\text { ratio } \\
(\%) \\
\end{array}$ & $>70$ & 75.6 \\
\hline & $\begin{array}{l}\text { Ductility }\left(10^{\circ} \mathrm{C}\right) \\
(\mathrm{cm})\end{array}$ & $>30$ & 40.8 \\
\hline
\end{tabular}

\begin{tabular}{|c|c|c|}
\hline $\begin{array}{c}\text { Equivalent softening point } \mathrm{T}_{800} \\
\left({ }^{\circ} \mathrm{C}\right)\end{array}$ & $>50$ & 61.0 \\
\hline Equivalent brittle point $\mathrm{T}_{1.2}\left({ }^{\circ} \mathrm{C}\right)$ & $<-13$ & -18.4 \\
\hline Flash point $(\mathrm{COC})\left({ }^{\circ} \mathrm{C}\right)$ & $>250$ & 277 \\
\hline Elastic recovery $\left(15^{\circ} \mathrm{C}\right)$ & $>80$ & 92.3 \\
\hline
\end{tabular}

From the results, it appears that all the performance indicators meet the technical requirements, we can use this asphalt.

\subsection{Coarse aggregate and fine aggregate}

\section{(1) Coarse aggregate}

There are basalt coarse aggregates $(10 \sim 20 \mathrm{~mm}$ 、 $5 \sim 10 \mathrm{~mm}$ ) and limestone (3 5mm ) aggregates, We tests the aggregate indexes in accordance with the relevant regulations, the test results are shown on the table below.

Table2. The coarse aggregate technical indicators

\begin{tabular}{|c|c|c|}
\hline $\begin{array}{l}\text { Aggregate } \\
\text { size }\end{array}$ & Test results & Test items \\
\hline $10 \sim 20 \mathrm{~mm}$ & 2.784 & \multirow{3}{*}{$\begin{array}{c}\text { Bulk specific } \\
\text { gravity }\end{array}$} \\
\hline $5 \sim 10 \mathrm{~mm}$ & 2.840 & \\
\hline $3 \sim 5 \mathrm{~mm}$ & 2.747 & \\
\hline $10 \sim 20 \mathrm{~mm}$ & 2.922 & \multirow{3}{*}{$\begin{array}{l}\text { Apparent } \\
\text { specific } \\
\text { gravity }\end{array}$} \\
\hline $5 \sim 10 \mathrm{~mm}$ & 2.980 & \\
\hline $3 \sim 5 \mathrm{~mm}$ & 2.907 & \\
\hline
\end{tabular}

From the results, it appears the bulk specific gravity and the apparent specific gravity all meet the technical requirements, we can use them in the project.

*Email Address: zhao_kunyang@126.com 
Table3. The coarse aggregate particle gradation

\begin{tabular}{|c|c|c|c|c|c|c|}
\hline \multirow{3}{*}{$\begin{array}{c}\text { mes } \\
\mathrm{h} \\
/ \mathrm{mm}\end{array}$} & \multicolumn{6}{|c|}{$\mathrm{P}(\%)$} \\
\hline & \multicolumn{2}{|c|}{$10 \sim 20 \mathrm{~mm}$} & \multicolumn{2}{|c|}{$5 \sim 10 \mathrm{~mm}$} & \multicolumn{2}{|c|}{$3 \sim 5 \mathrm{~mm}$} \\
\hline & $\begin{array}{l}\text { Technical } \\
\text { requirem } \\
\text { ents }\end{array}$ & $\begin{array}{c}\text { Test } \\
\text { resul } \\
\text { ts }\end{array}$ & $\begin{array}{c}\text { Technica } \\
1 \\
\text { requirem } \\
\text { ents } \\
\end{array}$ & $\begin{array}{c}\text { Test } \\
\text { resul } \\
\text { ts }\end{array}$ & $\begin{array}{c}\text { Technica } \\
1 \\
\text { requirem } \\
\text { ents } \\
\end{array}$ & $\begin{array}{c}\text { Test } \\
\text { results }\end{array}$ \\
\hline 19 & $95 \sim 100$ & 100 & - & & - & \\
\hline 16 & - & 95.4 & & & & \\
\hline 13.2 & - & 46.9 & 100 & 100 & - & \\
\hline 9.5 & $0 \sim 15$ & 2.1 & $95 \sim 100$ & 98.4 & - & \\
\hline 4.75 & $0 \sim 5$ & 0 & $0 \sim 10$ & 0.9 & $85 \sim 100$ & 97.8 \\
\hline 2.36 & - & 0 & $0 \sim 5$ & 0.1 & $0 \sim 25$ & 29.3 \\
\hline 1.18 & - & 0 & - & 0 & - & 11.1 \\
\hline 0.6 & - & 0 & - & 0 & $0 \sim 5$ & 5.3 \\
\hline 0.3 & - & 0 & - & 0 & - & 2.9 \\
\hline 0.15 & - & 0 & - & 0 & - & 2.1 \\
\hline $\begin{array}{c}0.07 \\
5\end{array}$ & - & 0 & - & 0 & - & 0.6 \\
\hline
\end{tabular}

From the results, it appears that the $4.75 \mathrm{~mm}$ and $2.36 \mathrm{~mm}$ passing rate of $3 \sim 5 \mathrm{~mm}$ cannot meet the technical requirements. So we suggest that We should screen $3 \sim 5 \mathrm{~mm}$ until the passing rate meet technical requirements.

(2) Fine aggregate

We use $0-3 \mathrm{~mm}$ fine aggregate, we test their performance indicators, and put them on the below table.

Table4. The basalt fine aggregate particle gradation

\begin{tabular}{|c|c|c|}
\hline \multirow{2}{*}{$\begin{array}{c}\text { mesh } \\
(\mathrm{mm})\end{array}$} & Pechnical requirements & Test results \\
\cline { 2 - 3 } & 100 & 100 \\
\hline 4.75 & $85 \sim 100$ & 92.3 \\
\hline 2.36 & $20 \sim 50$ & 56.1 \\
\hline 1.18 & & 37.8 \\
\hline 0.6 & & 19.2 \\
\hline 0.3 & $0 \sim 15$ & 12.1 \\
\hline 0.15 & & 2.9 \\
\hline 0.075 & & \\
\hline
\end{tabular}

From the results, it appears that $0 \sim 3 \mathrm{~mm}$ can meet the technical requirements.

\subsection{Filler}

We use the limestone powder filler, we test its performance indicators, we put the results on the table 5 .
Table5. The mineral filler technical indicators

\begin{tabular}{|c|c|c|c|}
\hline \multicolumn{2}{|c|}{ Test items } & $\begin{array}{c}\text { Technical } \\
\text { requirements }\end{array}$ & Test results \\
\hline \multicolumn{2}{|c|}{ Hydrophilic coefficient } & $\leq 1$ & 0.6 \\
\hline \multirow{2}{*}{$\begin{array}{c}\text { Particle } \\
\text { gradation }\end{array}$} & $<0.6 \mathrm{~mm}$ & 100 & 99.4 \\
\cline { 2 - 4 } & $<0.15 \mathrm{~mm}$ & 99.5 & 96.3 \\
\hline \multicolumn{2}{|c|}{$\begin{array}{c}\text { Apparent specific gravity } \\
\left(\mathrm{g} / \mathrm{cm}^{3}\right)\end{array}$} & 85.2 & 83.7 \\
\hline \multicolumn{2}{|c|}{ Water content $(\%)$} & $\leq 1$ & 2.669 \\
\hline
\end{tabular}

From the results, it appears that all the performance indicators meet the technical requirements, we can use this filler.

\subsection{Fiber}

We use polyacrylonitrile fiber to test, its main technical indicators are shown in table 6.

Table6. Polyacrylonitrie fiber test results

\begin{tabular}{|c|c|c|}
\hline Test items & $\begin{array}{c}\text { Technical } \\
\text { requirements }\end{array}$ & Test results \\
\hline $\begin{array}{c}\text { Diameter } \\
(\mu \mathrm{m})\end{array}$ & $10 \sim 25$ & 12.9 \\
\hline Length $(\mathrm{mm})$ & $6 \pm 1.5$ & 6.0 \\
\hline $\begin{array}{c}\text { Tensile strength } \\
(\mathrm{MPa})\end{array}$ & $\geq 500$ & 546 \\
\hline $\begin{array}{c}\text { Elongation at } \\
\text { break }(\%)\end{array}$ & $\geq 15$ & 20 \\
\hline
\end{tabular}

From the chart, we can see all the indicators of polyacrylonitrile fiber meet the specification requirements.

\subsection{Anti-rutting agent}

We use haichuan Anti-rutting agent, through results, Adding $0.5 \%$ anti-rutting agent of the asphalt mixture we can achieve the best test results. We test its performance indicators, and put the results on the below table.

Table7. Anti rutting agent basic indexes test results

\begin{tabular}{|c|c|c|}
\hline Test items & $\begin{array}{c}\text { Technical } \\
\text { requirements }\end{array}$ & Test results \\
\hline Density $\left(\mathrm{g} / \mathrm{cm}^{3}\right)$ & $0.9 \sim 1.1$ & 0.96 \\
\hline $\begin{array}{c}\text { Melt flow rate }\left(190^{\circ} \mathrm{C},\right. \\
2.16 \mathrm{~kg})(\mathrm{g} / 10 \mathrm{~min})\end{array}$ & $\geq 3$ & 8 \\
\hline Water content $(\%)$ & $\leq 2$ & 0.2 \\
\hline Softening point $\left({ }^{\circ} \mathrm{C}\right)$ & $140 \sim 170^{\circ} \mathrm{C}$ & 141 \\
\hline
\end{tabular}

From the results, it appears that all the performance indicators meet the technical requirement. 


\section{Mix design of SMA-16 asphalt mixture}

\subsection{The determination of aggregate gradation ratio}

The aggregate gradation ratio of SMA-16 asphalt mixture is formed with five different raw materials. We choose three mix designs. All the mix designs and raw materials are put on the below table.

Table8. SMA-16 ratio of mineral aggregate gradation(\%)

\begin{tabular}{|c|c|c|c|c|c|}
\hline $\begin{array}{c}\text { Specification } \\
\mathrm{s}\end{array}$ & $\begin{array}{c}10 \sim 20 \mathrm{~m} \\
\mathrm{~m}\end{array}$ & $\begin{array}{c}5 \sim 10 \mathrm{~m} \\
\mathrm{~m}\end{array}$ & $\begin{array}{c}3 \sim 5 \mathrm{~m} \\
\mathrm{~m}\end{array}$ & $\begin{array}{c}0 \sim 3 \mathrm{~m} \\
\mathrm{~m}\end{array}$ & $\begin{array}{c}\text { fille } \\
\mathrm{r}\end{array}$ \\
\hline $\begin{array}{c}\text { Coarse } \\
\text { gradation }\end{array}$ & 15 & 24 & 10 & 26 & 5 \\
\hline $\begin{array}{c}\text { Middle } \\
\text { gradation }\end{array}$ & 15 & 24 & 10 & 26 & 5 \\
\hline $\begin{array}{c}\text { Fine } \\
\text { gradation }\end{array}$ & 15 & 24 & 10 & 26 & 5 \\
\hline
\end{tabular}

Table9. SMA-16 mineral synthesis aggregate gradation

\begin{tabular}{|c|c|c|c|c|c|}
\hline $\begin{array}{c}\text { Mesh } \\
\text { size(mm) }\end{array}$ & coarse & middle & fine & upper & lower \\
\hline 26 & 100.0 & 100.0 & 100.0 & 100 & 100 \\
\hline 19 & 100.0 & 100.0 & 100.0 & 100 & 100 \\
\hline 16 & 97.6 & 97.7 & 97.7 & 95 & 90 \\
\hline 13.2 & 73.5 & 75.0 & 75.6 & 70 & 60 \\
\hline 9.5 & 50.6 & 53.6 & 54.6 & 50 & 40 \\
\hline 4.75 & 22.2 & 26.1 & 28.1 & 26 & 20 \\
\hline 2.36 & 18.7 & 21.8 & 23.0 & 22.5 & 18 \\
\hline 1.18 & 15.4 & 17.6 & 18.3 & 18 & 14 \\
\hline 0.6 & 12.9 & 14.6 & 15.0 & 15.5 & 12 \\
\hline 0.3 & 9.2 & 10.3 & 10.5 & 13 & 10 \\
\hline 0.15 & 7.6 & 8.5 & 8.6 & 11.5 & 9 \\
\hline 0.075 & 5.9 & 6.4 & 6.5 & 10 & 8 \\
\hline
\end{tabular}

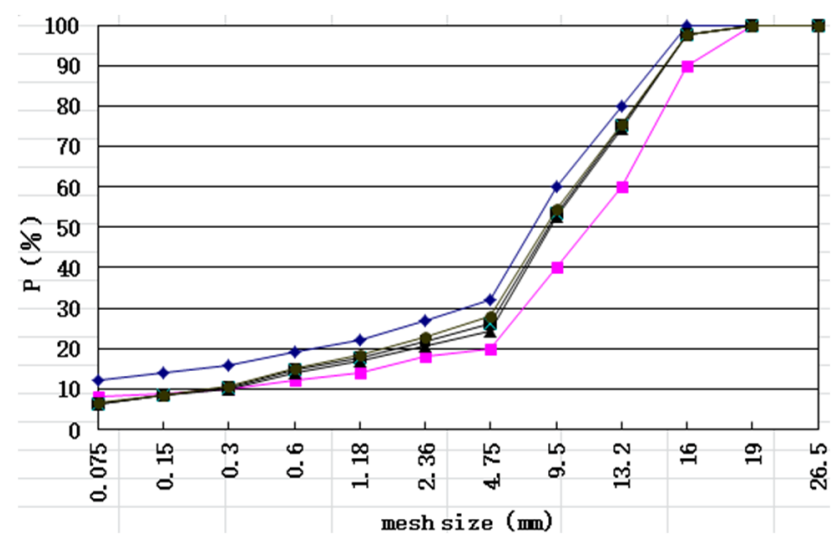

Figure 1. SMA-16 grading curve

Content of coarse aggregate $\mathrm{P}_{\mathrm{CA}}$ and Clearance rate $\mathrm{VCA}_{\mathrm{DRC}}$ of more than $4.75 \mathrm{~mm}$ in three mixtures are tested in table 10 .
Table10. The Marshall test results of different asphalt aggregate ratio

\begin{tabular}{|c|c|c|c|c|c|}
\hline items & $\begin{array}{c}\text { loose } \\
\text { unit } \\
\text { weight } \\
\left(\mathrm{g} / \mathrm{cm}^{3}\right)\end{array}$ & $\begin{array}{c}\text { the } \\
\text { passing } \\
\text { rate of } \\
4.75 \mathrm{~mm} \\
(\%)\end{array}$ & $\begin{array}{c}\text { bulk specific } \\
\text { gravity of } \\
\text { above4.75mm } \\
\left(\mathrm{g} / \mathrm{cm}^{3}\right)\end{array}$ & $\mathrm{P}_{\mathrm{CA}}$ & $\mathrm{VCA}_{\mathrm{DRC}}$ \\
\hline coarse & 1.720 & 22.2 & 2.799 & 0.734 & 38.55 \\
\hline middle & 1.706 & 26.1 & 2.779 & 0.697 & 38.61 \\
\hline fine & 1.700 & 28.1 & 2.773 & 0.678 & 38.69 \\
\hline
\end{tabular}

Based on the experience of previous similar airport engineering, we use ratio of $6.0 \%$ as a first try oil-stone ratio in Marshall design method, and then mold specimens in accordance with the specification requirements, measure the physical indexes of the specimens. Specific data are shown in table 11.

Table11. Performance of the first grading

\begin{tabular}{|c|c|c|c|}
\hline Test items & $\begin{array}{l}\text { Coarse } \\
\text { gradation }\end{array}$ & $\begin{array}{l}\text { Middle } \\
\text { gradation }\end{array}$ & $\begin{array}{c}\text { Fine } \\
\text { gradation }\end{array}$ \\
\hline $\begin{array}{l}\text { Bulk specific } \\
\text { gravity }\left(\mathrm{g} / \mathrm{cm}^{3}\right)\end{array}$ & 2.465 & 2.487 & 2.503 \\
\hline $\begin{array}{c}\text { Theoretical } \\
\text { density }\left(\mathrm{g} / \mathrm{cm}^{3}\right)\end{array}$ & 2.569 & 2.563 & 2.567 \\
\hline VV(\%) & 4.0 & 3.0 & 2.4 \\
\hline VMA(\%) & 17.04 & 16.06 & 15.47 \\
\hline VFA(\%) & 76.4 & 81.6 & 84.7 \\
\hline $\mathrm{VCA}_{\text {mix }}(\%)$ & 35.54 & 37.61 & 38.87 \\
\hline $\mathrm{VCA}_{\mathrm{DRC}}(\%)$ & 38.55 & 38.61 & 38.69 \\
\hline $\operatorname{MS}(\mathrm{KN})$ & 10.75 & 9.42 & 9.63 \\
\hline $\mathrm{FL}(0.1 \mathrm{~mm})$ & 34.1 & 36.9 & 34.2 \\
\hline
\end{tabular}

According to the relevant specifications, the coarse grading is the best grading.

\subsection{The determination of the optimum proportion}

We select 3 asphalt aggregate ratio of Marshall test and calculate their physical indicators in order to determine the optimum proportion, the test results are shown in the table12.

Table12. The Marshall test results of different asphalt aggregate ratio

\begin{tabular}{|c|c|c|c|c|}
\hline \multirow{2}{*}{ Test items } & \multicolumn{3}{|c|}{ oil-stone ratio(\%) } & \multirow{2}{*}{$\begin{array}{c}\text { Specification } \\
\text { requirements }\end{array}$} \\
\cline { 2 - 5 } & 5.7 & 6.0 & 6.3 & - \\
\hline $\begin{array}{c}\text { Bulk specific } \\
\left.\text { gravity(g/cm }{ }^{3}\right)\end{array}$ & 2.458 & 2.465 & 2.466 & - \\
\hline $\begin{array}{c}\text { Theoretical } \\
\text { density }\left(\mathrm{g} / \mathrm{cm}^{3}\right)\end{array}$ & 2.580 & 2.569 & 2.558 & - \\
\hline $\mathrm{VV}(\%)$ & 4.7 & 4.0 & 3.6 & $3 \sim 4$ \\
\hline VMA(\%) & 17.1 & 17.1 & 17.3 & $\geqslant 16.5$ \\
\hline
\end{tabular}




\begin{tabular}{|c|c|c|c|c|}
\hline \multirow{2}{*}{ Test items } & \multicolumn{3}{|c|}{ oil-stone ratio(\%) } & \multirow{2}{*}{$\begin{array}{c}\text { Specification } \\
\text { requirements }\end{array}$} \\
\cline { 2 - 4 } & 5.7 & 6.0 & 6.3 & \\
\hline $\mathrm{VFA}(\%)$ & 72.3 & 76.3 & 79.2 & - \\
\hline $\mathrm{VCA}_{\text {mix }}(\%)$ & 35.36 & 35.36 & 35.52 & $\leqslant \mathrm{VCA}_{\mathrm{DRC}}$ \\
\hline $\mathrm{VCA}_{\mathrm{DRC}}(\%)$ & 38.55 & 38.55 & 38.55 & - \\
\hline $\mathrm{MS}(\mathrm{KN})$ & 9.46 & 9.81 & 10.13 & $\geqslant 6$ \\
\hline $\mathrm{FL}(0.1 \mathrm{~mm})$ & 37.2 & 31.4 & 28.4 & - \\
\hline
\end{tabular}

According to the requirements of the relevant specification, calculated the optimum proportion of $6.0 \%$.

\subsection{The optimum proportion of validation}

In the optimum asphalt aggregate ratio of $6.0 \%$, we make Marshall specimen and the dynamic stability of specimen, then test their Physical and mechanical performance. we put the results on the below table.

Table13. The Road performance verification test results

\begin{tabular}{|c|c|}
\hline Test items & Test results \\
\hline$\triangle \mathrm{M}(\%)$ & 0.1 \\
\hline$\triangle \mathrm{S}(\%)$ & 1.81 \\
\hline $\mathrm{DS}(\mathrm{time} / \mathrm{mm})$ & 12000 \\
\hline $\mathrm{MSo}(\%)$ & 89.3 \\
\hline $\mathrm{TSR}(\%)$ & 91.6 \\
\hline $\mathrm{Cw}(\mathrm{mL} / \mathrm{min})$ & 32.1 \\
\hline $\mathrm{TD}(\mathrm{mm})$ & 1.1 \\
\hline
\end{tabular}

MS is strength index, MSo and TSR are water damage resistance index, DS is high temperature performance index, $\mathrm{Cw}$ is water permeability index.

From the results, it appears that all the test results can meet the requirements of related technologies.

Adding anti-rutting agent quality of $0.5 \%$ asphalt mixture, dynamic stability of asphalt mixture arrives at 12000 times $/ \mathrm{mm}$, MSo arrives at $89.3 \%$, TSR arrives at $91.6 \%, \mathrm{Cw}$ arrives at $32.1 \mathrm{~mL} / \mathrm{min}$. They all meet the design requirements. We can see that the mixture has formed the skeleton dense structure rom the profile of the specimen, it meets with the skeleton dense type $\mathrm{AC}$ asphalt mixture design intent.

\section{Conclusion}

In combination with the runway of Da Lian Airport, in order to slove the serious problems of SMA - 16 asphalt mixture, we achieve these important ways.

First; Starting from the raw material, we should choose the qualified raw materials. including aggregate, filler and asphalt. The important indicators of aggregate are bulk specific gravity, apparent specific gravity, sand equivalent, sturdiness and $\mathrm{p} \%$; The important indicators of filler are apparent specific gravity, water content, Particle gradation and hydrophilic coefficient; The important indicators of asphalt are penetration, softening point, ductility, equivalent softening point, equivalent brittle point $\mathrm{T} 1.2$, flash point, density, elastic recovery and filmy heating operational test $163^{\circ} \mathrm{C} / 5 \mathrm{~h}$.

Second: we should choose good aggregate gradation.such as $10 \sim 20 \mathrm{~mm}: 5 \sim 10 \mathrm{~mm}: 3 \sim 5 \mathrm{~mm}: 0 \sim$ $3 \mathrm{~mm}:$ fiber $=15: 24: 10: 26: 5$.

Third: In order to obviously improve the dynamic stability of mixture, it is reasonable to adding anti-rutting agent.

\section{References}

1. The ministry of communications highway engineering science institute. JTJ E20-2011.Standard test methods of bitumen and bituminous mixtures for highway engineering [S].

2. Xiaoming,Huang. Asphalt and asphalt mixture [M].

3. The ministry of communications highway engineering science institute. JTG F40-2004. Technical specification for construction of highway asphalt pavement [S].

4. The civil aviation administration of China. JTG F402004. Specification for asphalt concrete pavement construction of civil airports [S].

5. The ministry of communications highway engineering science institute. JTG E42-2005. Test methods of aggregate for Highway Engineering [S]. 